OPEN ACCESS

Indonesian Journal of Human Nutrition
P-ISSN 2442-6636
E-ISSN 2355-3987
www.jijnh.ub.acid
Artikel Hasil Penelitian

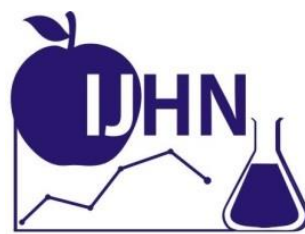

\title{
Pengaruh Pemberian Tepung Daun Katuk terhadap Penebalan Dinding Aorta Tikus Wistar
}

\section{(The Effect of Administering Katuk Leaf Powder on Wistar Rat's Aortic Wall Thickening)}

\author{
Olga Callista ${ }^{*}$, Dian Handayani ${ }^{1}$, Kanthi Permaningtyas Tritisari ${ }^{1}$ \\ Program Studi Ilmu Gizi Fakultas Kedokteran Universitas Brawijaya, \\ Jalan Veteran, Malang, Jawa Timur 65145 \\ * Alamat korespondensi, E-Mail: olgacallista@gmail.com
}

Diterima: / Direview: / Dimuat: Oktober 2014/ November 2014/ Desember 2015

\begin{abstract}
Abstrak
Kejadian aterosklerosis biasa diawali dengan cedera sel endotel yang menyebabkan peningkatan permeabilitas sel sehingga komponen plasma dapat masuk ke dalam dinding arteri, termasuk asam lemak. Akumulasi asam lemak dalam arteri dapat teroksidasi dan membentuk lapisan lemak di dinding arteri sehingga mengakibatkan penebalan dinding arteri dan penyempitan pembuluh darah. Salah satu terapi yang dapat mencegah peningkatan kadar lipid dalam darah adalah pemberian fitosterol. Daun katuk (Sauropus androgynus L. Merr) merupakan salah satu tanaman yang mengandung tinggi fitosterol. Penelitian ini bertujuan untuk mengetahui pengaruh pemberian tepung daun katuk berbagai dosis terhadap penebalan dinding aorta tikus putih Wistar yang diberi diet aterogenik. Penelitian ini menggunakan rancangan acak lengkap dengan Post Test Control Group Design yang dilakukan pada 30 ekor tikus Wistar jantan. Sampel dibagi menjadi 5 kelompok, yaitu Kelompok Negatif (diet normal), Kelompok Positif (diet aterogenik), Kelompok P1, P2, dan P3 yang diberi diet aterogenik dengan substitusi tepung daun katuk $6 \%, 9 \%$, dan $12 \%$. Pemberian tepung daun katuk diberikan setiap hari secara peroral melalui pakan selama 60 hari. Parameter yang diukur adalah tebal dinding aorta. Hasil uji statistik menunjukkan tidak terdapat perbedaan yang signifikan antar kelompok ( $p>0,05)$. Dari penelitian ini disimpulkan bahwa pemberian tepung daun katuk belum memberikan pengaruh terhadap penurunan ketebalan dinding aorta, sehingga disarankan untuk meningkatkan jangka waktu intervensi penelitian.
\end{abstract}

Kata kunci: penebalan dinding aorta, tepung daun katuk, diet aterogenik

\begin{abstract}
Atherosclerosis usually begins with endothelial cell injury which causes increased cell permeability. This injury will affect plasma component so that it can get into the arteries wall, that includes fatty acids. Accumulation of fatty acids in arteries can be oxidized and forms a layer of fat in the arterial wall that leads to thickening of the artery walls and narrowing of blood vessels. One of the therapies that can prevent the elevation of
\end{abstract}


plasma level is phytosterols therapy. Katuk leaf (Sauropus androgynus L. Merr) is a plant that contains high phytosterols. This study aims to determine the effect of various doses of katuk leaf powder on the aortic wall thickening of Wistar rats fed atherogenic diet. This study used a completely randomized design with post-test control group design on 30 male Wistar rats. The samples were divided into 5 groups, namely control negative group (normal diet), control positive group (atherogenic diet), P1, P2, and P3 groups were given atherogenic diet with katuk leaf powder substitution 6\%, 9\%, and $12 \%$ respectively. Katuk leaf powder was given orally every day for 60 days through feeding. The measured parameter was the aortic wall thickness. Statistical test results showed that there was no significant difference among the groups ( $p>0.05$ ). This study concludes that the administration of katuk leaf powder had no effects on decreasing the aortic wall thickness. Thus, it is advised to increase the duration of intervention.

Keyword: aortic wall thickness, katuk leaf powder, atherogenic diet

\section{PENDAHULUAN}

Aterosklerosis berasal dari kata Yunani 'sclerosis' yang berarti pengerasan dan 'athere' yang berarti bubur (akumulasi lipid). Fenomena ini ditandai dengan akumulasi kolesterol, infiltrasi makrofag, proliferasi sel otot polos, akumulasi komponen jaringan ikat dan pembentukan trombus [1]. Menurut teori stres oksidatif, aterosklerosis adalah hasil dari modifikasi oksidatif lipoprotein densitas rendah (LDL) di dinding arteri oleh spesies oksigen reaktif (ROS) [2].

Penyebab aterosklerosis berbeda-beda setiap individu, antara lain kolesterol serum yang tinggi, hipertensi, dan infeksi [3]. Hal ini didukung oleh faktor risiko yang terdapat pada masing-masing individu, antara lain faktor umur, riwayat keluarga, kebiasaan merokok, pola diet, dan aktivitas fisik [4,5].

Patofisiologi aterosklerosis diawali dengan disfungsi lapisan sel endotel pada lumen arteri yang dapat disebabkan oleh cedera sel endotel. Cedera endotel tersebut meningkatkan permeabilitas sel sehingga komponen plasma, seperti asam lemak, kolesterol dan trigliserida dapat masuk ke dalam arteri. Asam lemak di dalam arteri dapat teroksidasi dan menghasilkan radikal bebas yang dapat merusak pembuluh darah dan membentuk lapisan lemak di arteri [6].

Daun katuk telah lama dikenal sebagai pelancar air susu ibu (ASI). Dalam keadaan segar, daun katuk memiliki kandungan fitosterol dan flavonoid yang lebih tinggi jika dibandingkan dengan tanaman tropis lain yang dapat dikonsumsi [7,8]. Kandungan fitosterol daun katuk mencapai $2433,4 \mathrm{mg} / 100 \mathrm{~g}$ bahan kering atau setara dengan $466 \mathrm{mg} / 100 \mathrm{~g}$ bahan segar [7]. Fitosterol dikenal dengan kemampuannya menurunkan kadar kolesterol plasma dengan cara menghalangi absorbsi kolesterol pada sistem gastrointestinal [9]. Kandungan flavonoid pada daun katuk sebesar $143 \mathrm{mg} / 100 \mathrm{~g}$ bahan segar (832 mg/100 gram bahan kering) [8]. Flavonoid berfungsi sebagai antioksidan di dalam tubuh manusia yang memiliki efek protektif terhadap inisiasi dan perkembangan aterosklerosis [10].

Melihat manfaat daun katuk terhadap pencegahan aterosklerosis dan masih jarangnya penelitian mengenai manfaat daun katuk terhadap kejadian aterosklerosis pada hewan coba, maka penelitian ini bertujuan untuk mengetahui pengaruh pemberian tepung daun katuk terhadap penebalan dinding aorta tikus wistar yang diberi diet aterogenik.

\section{METODE PENELITIAN}

Penelitian ini menggunakan rancangan acak lengkap dengan Post Test Control Group Design yang dilakukan pada 30 ekor tikus putih Rattus norvegicus strain Wistar jantan yang berumur \pm 2 bulan dengan berat badan 150-200 gram. Jumlah sampel setiap kelompok perlakuan ditentukan oleh rumus Federer dan didapatkan hasil diperlukan 5 sampel per kelompok. Dalam penelitian ini digunakan 6 ekor tikus dalam setiap kelompok dengan 1 ekor sebagai cadangan [11]. 
Tikus dibagi menjadi 5 kelompok, yaitu kelompok K(-) yang diberi diet normal, kelompok $\mathrm{K}(+)$ yang diberi diet aterogenik, serta kelompok $\mathrm{P} 1, \mathrm{P} 2$, dan $\mathrm{P} 3$ yang diberi diet aterogenik dengan substitusi tepung daun katuk $6 \%, 9 \%$, dan $12 \%$. Sebelum penelitian dimulai, semua sampel diadaptasi dengan pakan normal selama 7 hari, selanjutnya diberi pakan sesuai dengan perlakuannya selama 60 hari. Tepung Daun Katuk (TDK) diberikan dengan cara dicampurkan pada pakan tikus dengan mensubstitusi tepung terigu. Selama penelitian berat badan tikus ditimbang setiap minggunya.

Variabel terikat adalah tebal dinding aorta tikus Wistar yang diukur pada akhir penelitian dengan dibuat sediaan histopatologi menggunakan metode pewarnaan HematoksilinEosin [12]. Variabel diukur menggunakan mikroskop cahaya dengan pembesaran 400x yang terhubung software Image Pro dengan menarik garis tegak lurus pada garis terdalam tunika intima hingga garis terluar tunika adventisia. Hasil pengukuran dianalisis menggunakan software SPSS 16. Untuk data yang berdistribusi normal dan homogen dianalisis dengan uji ANOVA. Selanjutnya dilakukan uji Post Hoc Tukey untuk mengetahui perbedaan dari masing- masing kelompok. Bila data tidak berdistribusi normal ataupun tidak homogen, dilakukan uji Kruskal Wallis dan dilanjutkan dengan uji MannWhitney untuk mengetahui perbedaan yang signifikan. Rancangan penelitian ini telah mendapat persetujuan Komisi Etik Penelitian Kesehatan Fakultas Kedokteran Universitas Brawijaya.

\section{HASIL PENELITIAN}

Rata-rata asupan pakan pada kelompok yang diberi diet normal merupakan rata-rata asupan yang paling tinggi di antara semua kelompok perlakuan. Meskipun demikian rata-rata asupan energi tidak berbanding lurus dengan jumlah pakan yang dikonsumsi karena pakan diet aterogenik mengandung energi yang lebih tinggi akibat penambahan lemak.

Peningkatan berat badan merupakan pertambahan berat badan tikus selama 60 hari masa perlakuan. Rata-rata peningkatan berat badan tikus selama perlakuan seperti yang terdapat pada Tabel 2 . Uji normalitas dan uji homogenitas menunjukkan data tebal dinding aorta tikus Wistar tidak berdistribusi normal namun bersifat homogen sehingga dilakukan uji Kruskal Wallis untuk mengetahui perbedaan antar kelompok.

Tabel 1. Komposisi Pakan Normal dan Pakan Aterogenik

\begin{tabular}{lcc}
\hline Bahan & Pakan Normal (\%) & $\begin{array}{c}\text { Pakan Aterogenik } \\
(\mathbf{\%})\end{array}$ \\
\hline PARS & 53 & 50 \\
Terigu & 23,5 & 25 \\
Kuning telur bebek & - & 5 \\
Lemak kambing & - & 10 \\
Minyak kelapa & - & 1 \\
Minyak babi & - & 8,9 \\
Asam kolat & - & 0,1 \\
Air & 23,5 & - \\
TOTAL & $\mathbf{1 0 0}$ & $\mathbf{1 0 0}$ \\
\hline
\end{tabular}

Tabel 2. Rata-rata Asupan Tikus

\begin{tabular}{ccccc}
\hline Kelompok & $\begin{array}{c}\text { Asupan Pakan } \\
(\mathbf{g})\end{array}$ & $\begin{array}{c}\text { Asupan Energi } \\
(\mathbf{k k a l})\end{array}$ & $\begin{array}{c}\text { Asupan } \\
\text { Lemak }(\mathbf{g})\end{array}$ & $\begin{array}{c}\text { Asupan } \\
\text { TDK }(\mathbf{g})\end{array}$ \\
\hline $\mathrm{K}(-)$ & $30,16 \pm 2,78^{\mathrm{b}}$ & $79,13 \pm 7,28^{\mathrm{a}}$ & $0,70 \pm 0,06^{\mathrm{a}}$ & $0^{\mathrm{a}}$ \\
$\mathrm{K}(+)$ & $21,96 \pm 3,03^{\mathrm{a}}$ & $102,80 \pm 13,87^{\mathrm{b}}$ & $5,39 \pm 0,73^{\mathrm{b}}$ & $0^{\mathrm{a}}$ \\
P1 & $22,83 \pm 2,64^{\mathrm{a}}$ & $104,98 \pm 12,16^{\mathrm{b}}$ & $5,49 \pm 0,64^{\mathrm{b}}$ & $1,37 \pm 0,16^{\mathrm{b}}$ \\
P2 & $22,49 \pm 7,00^{\mathrm{a}, \mathrm{b}}$ & $104,42 \pm 32,41^{\mathrm{a}, \mathrm{b}}$ & $5,47 \pm 1,70^{\mathrm{b}}$ & $2,03 \pm 0,63^{\mathrm{c}}$ \\
P3 & $19,96 \pm 5,13^{\mathrm{a}}$ & $90,96 \pm 23,85^{\mathrm{a}, \mathrm{b}}$ & $4,76 \pm 1,25^{\mathrm{b}}$ & $2,35 \pm 0,62^{\mathrm{c}}$ \\
\hline
\end{tabular}

*Data menunjukkan rata-rata asupan pakan tikus selama 24 jam. Rata-rata dengan huruf yang berbeda menunjukkan adanya perbedaan yang signifikan $(\mathrm{p}<0,05)$. 
Tabel 3. Peningkatan Berat Badan Tikus (gram)

\begin{tabular}{ccc}
\hline Kelompok & n & Mean \pm SD \\
\hline K (-) & 6 & $171,3 \pm 27,3^{\mathrm{b}}$ \\
K (+) & 6 & $161,3 \pm 20,3^{\mathrm{b}}$ \\
P1 & 6 & $154,2 \pm 45,0^{\mathrm{b}}$ \\
P2 & 6 & $127,3 \pm 47,4^{\mathrm{a}, \mathrm{b}}$ \\
P3 & 6 & $88,7 \pm 22,3^{\mathrm{a}}$ \\
\hline
\end{tabular}

*Analisis Mean \pm SD, menunjukkan peningkatan berat badan tikus selama penelitian. Rata-rata dengan huruf yang sama menunjukkan tidak berbeda signifikan $(\alpha=0,05)$.

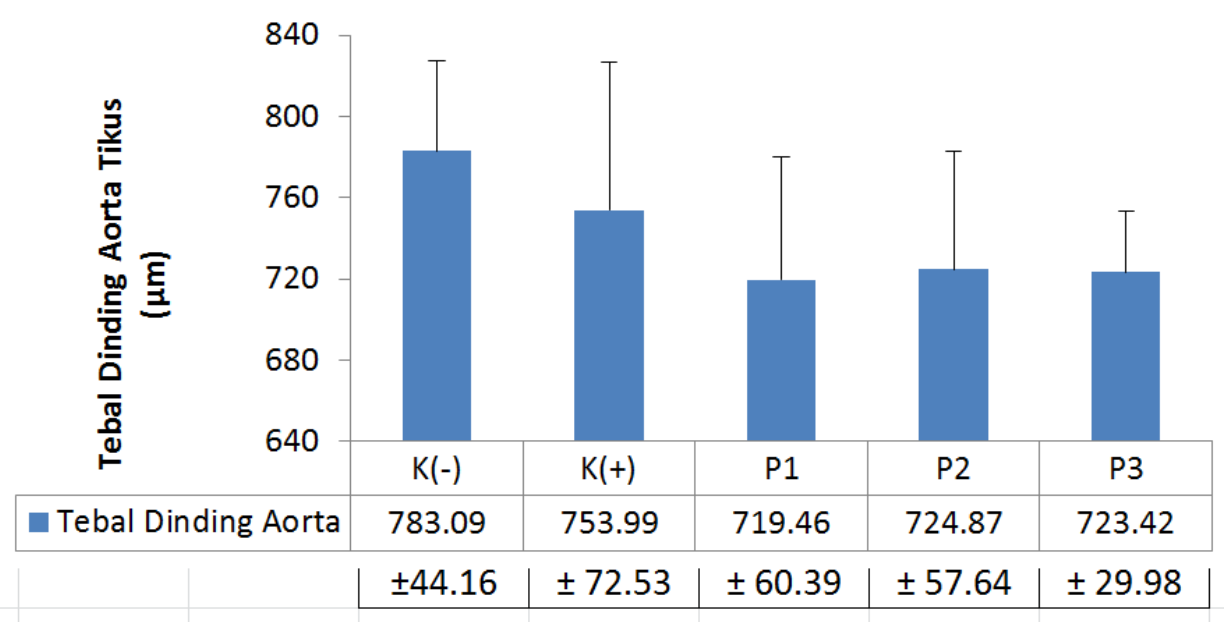

Hasil analisis dengan uji Kruskal Wallis menunjukkan tidak ada perbedaan yang signifikan antar kelompok perlakuan $(\mathrm{p}=0,221)$

Gambar 1. Ketebalan Dinding Aorta setelah mendapat perlakuan selama 60 hari.

\section{PEMBAHASAN}

Terdapat perbedaan jumlah asupan pakan yang signifikan antara kelompok $\mathrm{K}(-)$ dengan kelompok $\mathrm{K}(+)$, P1, dan P3. Perbedaan jenis pakan yang diberikan dapat mempengaruhi jumlah pakan yang dikonsumsi tikus [13]. Penurunan asupan tikus pada kelompok perlakuan TDK juga dapat disebabkan oleh faktor satiety tikus akibat kandungan serat yang cukup tinggi dalam pakan. TDK mengandung serat kasar sebesar $\pm 15,52 \%$ dari total beratnya [14]. Makanan tinggi serat akan dicerna lebih lama dalam lambung dan memberikan rasa kenyang lebih lama sehingga menurunkan konsumsi makanan [15]. Dilihat dari rata-rata asupan energi, jumlah energi yang dikonsumsi oleh kelompok P2 dan P3 hampir sama dengan jumlah energi yang dikonsumsi oleh tikus pada kelompok $\mathrm{K}(-)$ yang diberi diet normal.

Meninjau peningkatan berat badan tikus selama penelitian, asupan energi yang berbeda tidak berpengaruh pada peningkatan berat badan tikus. Kandungan serat yang tinggi dari pakan aterogenik + TDK dapat menjadi salah satu faktor yang mempengaruhi hasil tersebut. Serat dapat menurunkan absorbsi lemak dan menurunkan kadar kolesterol dalam darah [16]. Hal ini sebanding pada peningkatan berat badan tikus pada penelitian ini, yakni semakin tinggi asupan tepung daun katuk semakin rendah peningkatan berat badan tikus. Namun dalam penelitian ini tidak meneliti adanya lemak yang keluar melalui feses, sehingga tidak 
diketahui apakah serat maupun fitosterol dalam TDK mampu mengeliminasi lemak supaya tidak diabsorbsi oleh tubuh [17]. Selain energi, terdapat faktor lain yang juga dapat mempengaruhi berat badan tikus, yaitu faktor aktivitas dan faktor stress tikus $[18,19]$ namun hal tersebut tidak diteliti dalam penelitian ini.

Hasil penelitian menunjukkan bahwa tebal dinding aorta $\mathrm{K}(-), \mathrm{K}(+), \mathrm{P} 1, \mathrm{P} 2$, dan $\mathrm{P} 3$ tetap normal sampai akhir penelitian. Tidak ditemukan adanya plak aterosklerosis pada semua sampel penelitian. Hasil ini bisa disebabkan karena kurangnya jumlah asam kolat dan kolesterol yang diberikan [20], serta kurangnya masa intervensi penelitian.

Penggunaan tikus sebagai hewan coba juga mempengaruhi hasil penelitian ini. Secara alamiah, tikus resisten terhadap aterosklerosis kecuali tikus dengan galur C57BL/6 yang peka terhadap diet hiperkolesterol. Berbeda dengan manusia, tikus memiliki lebih banyak kolesterol HDL di dalam plasma darahnya yang mencegah terjadinya penumpukan lemak dalam darah sehingga perlu manipulasi genetik apabila menggunakan tikus sebagai hewan coba untuk aterosklerosis. Meski demikian, penelitian lain menunjukkan pemberian diet tinggi lemak menghasilkan lesi yang sedikit dan hanya terbatas pada pembentukan sel busa.

\section{KESIMPULAN}

Pemberian tepung daun katuk dalam campuran pakan tidak memberikan pengaruh yang nyata terhadap penebalan dinding aorta tikus Wistar jantan yang diberi diet aterogenik. Penggunaan hewan coba yang tepat juga diperlukan untuk memperoleh hasil penelitian yang lebih akurat.

\section{DAFTAR RUJUKAN}

1. Singh RB, Mengi SA, Xu YJ, Arneja AS, Dhalla NS. Pathogenesis of Atherosclerosis:A Multifactorial Process. Exp Clin Cardiol. 2002; 7(1): 40-53.

2. Vogiatzi G, Rousoulis D, Stefanadis C. The Role of Oxidative Stress in Atherosclerosis. Hellenic J Cardiol. 2009; 50: 402-409.

3. Corwin EJ. Buku Saku Patofisiologi, Edisi 3. Terjemahan oleh Nike BS. Jakarta: Penerbit Buku Kedokteran EGC. 2009.

4. National Institutes of Health. Detection, Evaluation, and Treatment of High Blood Cholesterol in Adults (Adult TreatmentPanel III). 2002. NIH Publication No. 02-5215.

5. British Heart Foundation. Coronary Heart Disease Statistics in England, 2012.London; 2012.
6. Mughni A. Pengaruh Puasa Ramadhan Terhadap Faktor-Faktor Risiko Aterosklerosis: Studi Pada Profil Lipid, Gula Darah, Tekanan Darah dan Berat Badan. Dipublikasikan. Semarang: Universitas Diponegoro; 2007.

7. Subekti S, Piliang WG, Manalu W, Murdiati TB. Penggunaan Tepung Daun Katuk dan Ekstrak Daun Katuk (Sauropus androgynus L.Merr) sebagai Substitusi Ransum yang Dapat Menghasilkan Produk Puyuh Jepang Rendah Kolesterol. JITV. 2006; 11(4): 254-259.

8. Andarwulan N, Batari R, Sandrasari DA, Bolling B, Wijaya H. Flavonoid Content And Antioxidant Activity Of Vegetables From Indonesia. Food Chemistry. 2010; 121: 1231-1235.

9. Sukmaniah S, Bardosono S, Oetoro S, Permadhi I, Lestarina L. The Effects Of Phytosterol In Low Fat Milk On Serum Lipid Levels Among MildModerately Hypercholesterolemic Subjects.Med J Indones. 2008; 17(1): 5- 12.

10. Grassi D, Desideri G, Ferri C. Flavonoids: Antioxidants Against Atherosclerosis. Nutrients. 2010; 2: 889-902.

11. Maliya A. Perbedaan Profil Lipid Serum dan Perkembangan Lesi Aterosklerotik Aorta Abdominalis Antara Yang Diberi Perasan Pare (Momodica charantia) dan Kontrol. Semarang: Universitas Diponegoro; 2006.

12. Noviyanti. Perbedaan Left Ventricular Ejection Fraction (LVEF) dan End Sistolic Dimension (ESD) pada Penderita Regurgitasi Mitral Kronik Sebelum dan Sesudah Mitral Valve Replacement. Semarang: Universitas Diponegoro; 2009.

13. Marliyati SA, Syariel H, Muchtadi D, Darusman LK, Rimbawan, Priosoerjanto BP. Pengaruh Sterol Lembaga Gandum (Triticum sp.) Terhadap Profil Lipida Darah Tikus. Media Gizi \& Keluarga. 2004; 28(2): 54-67.

14. Septyana, M. Performa Itik Petelur Local Dengan Pemberian Tepung Daun Katuk (Sauropus Androgynus (L.) Merr.) Dalam Ransumnya. Bogor: Fakultas Peternakan Institut Pertanian Bogor; 2008.

15. Santoso A. Serat Pangan (Dietary Fiber) dan Manfaatnya Bagi Kesehatan. Magistra. 2011; 75: 35-40.

16. Sulastri D, Rahayuningsih S, Purwanyastuti. Pola Asupan Lemak, Serat, dan Antioksidan, serta Hubungannya dengan Profil Lipid pada Laki-laki Etnik Minangkabau. Maj Kedokt Indon. 2005; 55(2): 61-66. 
17. Rideout TC, Harding SV, dan Jones PJ. Consumption of Plant Sterols Reduces Plasma and Hepatic Triglycerides and Modulates The Expression of Lipid Regulatory Genes and De Novo Lipogenesis In C57BL/6 J Mice. Mol Nutr Food Res. 2010; 54(1):S7-S13.

18. Sudiarto, Suprihatin SH. Pengaruh Pemberian Quercetin Terhadap Kadar Leptin Serum Tikus Wistar Yang Diberi Diet Tinggi Lemak. Jurnal Saintika Medika [serial online]. 2010 (Diunduh 20 Agustus 2014); 6(13): 9-27. Available from: http://ejournal.umm.ac.id/.

19. Kristyanto H, Sonia S, Natsir PRA, Suraya F, Ibrahim N. Pengaruh Musik Klasik dan Musik Rock Terhadap Nafsu Makan dan Berat Badan Tikus. Maj Kedokt Indon. 2010; 60(5): 219-226.

20. Murwani S, Mulyohadi A, Ketut M. Diet aterogenik pada Tikus Putih (Rattus novergicus strain Wistar) Sebagai Model Hewan Aterosklerosis. Jurnal Kedokteran Brawijaya. 2005; XXII (1): 6-9. 